\title{
Metaphor in Students' English Poems: A Psycholinguistic Analysis
}

\author{
ADRIANSYAH ABU KATILI \\ Universitas Negeri Gorontalo \\ adriansyahkatili@ung.ac.id
}

\begin{abstract}
This research is aimed at finding out how the students of English Department of State University of Gorontalo perceive the thing as revealed in the metaphor they used in their English Poem and interpreting the metaphor. The research was designed using a qualitative research methodology. The source of data was from the poems written by the students in 2010. It is found that the students used metaphor to express their feelings. The metaphor reflects the students' perception of the reality categorized in semantic fields. In terms of the intended meaning of the metaphor, the researcher inferred the meaning by finding the metaphor predications based on the researcher knowledge of the predication.
\end{abstract}

Keywords: metaphor; semantic fields; predications

\section{INTRODUCTION}

This article is aimed at revealing how the metaphor in the poems created by the students of English Department reflected their perception of the reality. The theory applied for this analysis was the theory of psycholinguistic which says that the perception of human is distributed into nine Semantic Fields introduced by Haley as cited in Wahab (1991) that is discussed elaborately in the other session of this article. This analysis is considerably important in order to understand that the man's perception of the reality is reflected in metaphor use and the semantic field of the metaphor is influenced by the perception. This discussion is more phsycholinguistically because this is related to the perception as reflected by the use of metaphor.

\section{LITERATURE REVIEW THE NATURE OF METAPHOR}

According to Wahab (1991) metaphor is the way of saying something in other term. Therefore, when people say Time is money they are saying that time is the valuable thing as money. They say the importance of time in term of money. This perception seems to be influenced by the perception losing money means losing life. Therefore, losing time means loosing money.

Lakoff and Johnson $(1981,2005)$ say that the essence of metaphor is understanding and experiencing one thing in term of another. The previous example of argument suggests how human understand and experience argument in terms of war. Wahab (1991) says that metaphor is a verbal expression that combines the predications of the symbol and the intended meaning. Thus, when one says "Jane in an iceberg" the hearer should refer to the predication of the iceberg as follows: 
1. Frozen

2. Dangerous

3. Mysterious

Hence, the intended meaning of the metaphor is "Jane is frozen, mysterious, and therefore, is dangerous."

Metaphor has been used widely in human's language. It is used in every genre of language, literary genre and non-literary genre. In this sense, Lakoff and Johnson (1980) reported that there is a phenomenon that metaphor has been an essential device of thinking and acting. The following example shows how people think argument in metaphor of war:

\author{
ARGUMENTS IS WAS \\ Your claims are indefensible \\ He attack every weak point in my argument \\ His criticisms were right on target \\ I demolished his argument \\ I've never won an argument with him \\ You disagree? Okay, shoot! \\ If you use that strategy, he'll wipe you out. \\ He shot down all of my arguments.
}

The above example shows us how people think of perceive argument in war metaphor. This indicates that metaphor is not only an ornamental use of language that is consequently not needed in our life as asserted by the positivists, but it is also the way of thinking.

Lakoff and Johnson's opinion above is in line with Kôveeses (2010) who says that metaphor has been a phenomenon in daily natural way of communication. It is to concrete the abstract concept and so can be perceived by the hearer/reader. Kwedju (2005) observed that metaphor can potentially influence human's perception of something. She specified her observation on the phenomenon in Indonesia. In Indonesia, there was a tendency of borrowing metaphor from foreign language with culture that is totally different from Indonesia. The borrowed metaphors are mostly about economy that consequently potentially impacts lead the Indonesians to be materialistic. Take the example of the metaphor Time is money.

Lihawa (1999) reported an investigation on the metaphor used in Gorontaleese wedding ceremonial. She focused on the metaphor in the Tujai, i.e. ritual poetry spoken in a Gorontaleese wedding custom ceremonial. This poetry contains metaphorical message to the newly couple married. Wahab (1986) in his research on Javanese metaphor found that Javanese use metaphor in communication to express their thought. This indicates that metaphor has been the way of thinking of the Javanese.

The above examples happen in the use of non-literary language. In literary use of language, especially poetry, the use of metaphor is more intense. Deichess (1964) says that poetry uses intellectual meaning of words that is rich of meaning. If we agree with this statement, then we agree that poet uses metaphor in his/her metaphor. Chomsky (1972) says that poetry is the intellectual use of language. Therefore, metaphor which is also known as a creative use of intellectual meaning of words can be found in poetry.

Metaphor has been one of the elements of poetry. Robert Frost, an American famous poetry is the art of saying one thing and meaning in another (Wahab, 1991). Kôvecses (2010) said that 
metaphor is used in literature as in ordinary use of language. However, poet tends to be more creative in using metaphor when composing a poem. Ntou (1999) investigated the use of metaphor in Robert Frost's poems and he found that Frost was very creative in using metaphor in his poems.

\title{
TWO OPPOSITE OPINIONS ABOUT METAPHORS
}

According to Wahab (1991), the history of metaphor had been debated by two different views. The first is that of positivists who say that metaphor is reflection of bad behavior of unwillingness to think analytically. Metaphor will lead people to the misunderstanding toward the message the writer or speaker wants to convey. The relativist, on the other hands, thinks that metaphor is the mental process of perceiving the reality. The two people, Sapir and Whorf, say that reality is not constructed directly by the people; instead it is constructed on the bases of human's knowledge and language. This opinion lead the some people to think that metaphor is important to construct human's knowledge of reality. The thinkers that stand for this side are Black, Boyd, Kuhn, and Petrie.

\section{METAPHOR AND PSYCHOLINGUISTIC}

Hatley as cited in Pateda (1990) says that psycholinguistics is the branch of linguistics that investigates the interrelation between language and mind in processing and producing utterances and language acquisition. The interrelation between psycholinguistics and metaphor is that the process of one's mind when producing a metaphor. The relation is how the speaker/writer perceives the reality and expresses it metaphorically. The keywords are how the speaker/writer perceives and expresses it. Therefore, it lies on perception and expression. Therefore, we should refer to how human perceives reality. As Wahab says, the speaker/writer is influenced by the environment surrounding him/her. This leads us a theory of human perception proposed by Halley.

Halley (in Wahab, 1991) says that the category of human's perception is structured in the hierarchy semantic field as follows:

\author{
BEING \\ COSMOS \\ ENERGY \\ SUBSTANCE \\ TERRESTERIAL \\ OBJECT \\ LIVING \\ ANIMATE \\ HUMAN
}


The structure suggested that human is the sub-ordinate of animate; animate is the subordinate of living and so on and finally we come to the cosmos that is in the highest position. Every semantic field has the samples of nominate and predication explained in the following table 1:

TABLE 1. Examples of Nominate and Predication

\begin{tabular}{lll}
\hline Category & Nominate & Predications \\
\hline Being & Truth, love & Being \\
\hline Cosmos & Sun, earth, moon & In space \\
\hline Energy & Light, wind, fire & Moving \\
\hline Substance & Gas & Soft \\
\hline Terrestrial & Mount, river, sea & Landscape \\
\hline Object & Minerals & Fragile \\
\hline Living & Flora & Growing \\
\hline Animate & Fauna & Walking, run \\
\hline Human & Human & Thinking \\
\hline
\end{tabular}

Thus, when Thomas Campion says "There is a garden in her face", he uses a metaphor under the category of flora to mean the beauty of a woman.

Metaphor as the way of thinking and perceiving reality contains the semantic field. A study on this was conducted by Wahab and reported in his dissertation entitled Javanese Metaphor in Discourse Analysis (1986). Wahab reports that he found that Javanese metaphor reflected the Javanese perception on reality reflects the semantic fields discussed by Halley. Various data that he has analyzed suggested that Javanese people reflect their perceptions on reality are distributed in the semantic fields.

\section{METHOD}

This research was conducted using a content analysis, i.e. the analysis focused on a document as the data source. The document to be analyzed was the students' poem, i.e. the students of English Department of the State University of Gorontalo. In this research the data was analyzed based on Wahab (1991) model of analysis conducted by finding the metaphorical statement. The model of analysis was conducted to find the three components attached in the significant used of the metaphor as follows:

1. Predication that might be attached to the signifier and may be used as the signified.

2. Two kinds of experiential gestalt, i.e. our observation of the metaphorical statement itself and its intended meaning.

3. Semantic and pragmatic interpretation.

The interpretation of the metaphor discussed above was based on the predications and followed by the process of classification according to Halley's category of semantic field.

\section{FINDINGS}

The researcher found 128 categories of metaphor taken from 59 poems written by the students of English Department who were enrolling into the class of Poetry in 2010. The research findings are displayed in this session and then they are discussed. The metaphors are categorized in the semantic fields discussed previously. 


\section{HUMAN}

Human category was found in some poems. The sample poem below was written by Ayu Amelia Lihawa which was untitled. Human category read in the following lines:

\section{Even though I am not spiderman}

or superman.

The poem seems to be addressed to someone which seems to be her close friend. The predications of Spiderman and superman are:

1. $\quad$ Strong

Therefore, the metaphor Spiderman and superman means that she is not as strong as the hero, she wants to care for him.

The other metaphor belongs to human category was found in poem entitled Love by Irmawaty. This poem expressed the sadness caused by love as reads in the following lines:

Love is strong power in world

But sometimes makes me sad

The keyword is the verb makes. This is an activity that can be done by human. Thus, love is perceived as human that has the ability to make the poet sad.

The next metaphor under human category is found in Rafika Paputungan's poem entitled Teacher. In this poem, she seems to admire her teacher. She metaphorically says You are my parents. Here, you refer to the teacher as suggested by the title. In this line she perceives her teacher as her parents. Parents' predications are:
1. Protection
2. Love
3. Caring
4. Guidance

Thus, the metaphor you (teacher) are my parents means that her teacher is the person who protects. Loves, cares, and guides her, as the parents did. below.

The other metaphor under human category was found in the same poem as read in the lines

\section{Teacher... \\ You are my hero}

In that line the student perceives her teacher as her hero. The predications of hero are:

1. Protection

2. Struggler

3. Respected

4. Brave

5. A person who have done a big thing for the other.

Unlike the previous metaphor, in case of this metaphor we should choose the most possible predication to come to the most possible interpretation of the intended meaning. The most possible meanings are struggler and respected. The teacher is a person who struggle to teach the students, to open their eyes to see the world, and therefore s/he is respected. 
ANIMATE

The metaphor categorized as animate was found in Elvira Maulana's poem entitled Butterfly. It is described as an insect fly happily. Here is the stanza containing it:

Hoping to catch your eye

Circling around you

Oh my butterfly, butterfly, come into the light

Oh, what a beautiful sight flying so gracefully

To infer the poet's intended meaning we need to analyze the predications of butterfly as follows:

1. It is a beautiful insect

2. It flies in happy manner

The predications are attached to this insect. However, this is not a butterfly in literal meaning. If we agree that the language of poetry is metaphor as discussed previously, then we agree that this is a metaphor. Through this metaphor, the poet perceives the happiness and beauty in animate semantic field category.

LIVING

This category is found in Uliyah's Rose. Uliyah presents rose to mean metaphorically happiness. It reads in the following quotation:

Rose...

Your shape is beautiful

Your smell is fragrant aromatic

Your color is bright red

Like heart color

Unlike the previous metaphors, the poet put the predication of rose in the next lines. It is beautiful in shape; its smell in fragrant aromatic, its color is bright red like heart color. The entire predications indicate happiness. Therefore, rose in this poem metaphorically means the happiness and beauty.

In the following poem entitled Peace by Ni Wayan Purnamasari, the author perceives as tree that is categorized living.

Peace is in fresh air

Peace is in fresh water

Peace is under green tree

Where air blows calming the earth

Where water is streaming in shining

As the metaphor of rose in above poem, the poet presents the predication of green tree in the previous line and that follows it. They are:

1. Surrounded by fresh air

2. Fresh water is under it

3. Surrounded by air blows calming the earth

4. Water is streaming in shining.

The entire predications suggest the peaceful life when we are close to nature.

OBJECT

The metaphor categorized as object is found in Hermin Suleman's poems Money. It reads: 


\section{Money...Moony...Money}

\section{Is needed human}

But they don't use with good

So that, now the people's foolish with money

Money is categorized object; it fragile. Its predications are as follows:

1. Invaluable thing

2. Used for transaction

3. The cause of conflict.

4. The reason for the men to work hard.

By knowing the predications, we can infer that money was intended to mean invaluable thing used for transaction, the reason for the men to work hard. But it cause conflict among men. Thus, metaphorically, it is the metaphor of life of human that is multidimensional.

\section{TERRESTERIAL}

The metaphor categorized as terrestrial was found in Novianti A. H. Mahmud's God. In this poem she perceived God as a "place" in which she can request everything. The lines sample of the poem are as follows:

You are my better place for request

When hopeless starting enter in my life

The predications of place are:

1. A location where people life

2. A Location where people do activities

In this poem the poet perceives God as the place in which she put her request, hope, expectation.

\section{SUBSTANCE}

The metaphor categorized in this semantic field was from Ain Haru's Great Woman. The metaphor in this poem is Sweat and Tears compared in your face. Sweat is associated with hard work, and tears is associated with sadness. Therefore, Ain perceives her mother's hard working in the substances of sweat and tears.

ENERGY

There are two data samples relating to the energy presented in this article. The first one is that in Muthmainnah Nasaru's I'm Hurt Because of You as follows:

Friend...

Only cry as my release

The words release is a metaphor categorized in energy because it is a moving thing. In this poem, this word is related to the activity of crying. Therefore, to cry is perceived as the energy to release the feeling of being hurt.

The second one is that in Jein Setiawan's Traitor of Love. She uses wind of night to mean negative energy that break her love, as can be seen in the following data sample:

When my heart could not lovin

I felt bareness and loneliness in my night

Love that I hope come to my life

Now it had gone swallowed by the wind of night 
Wind of the night refers to the energy of wind that is blowing in the night. In Indonesian culture, wind of the night is associated with negative energy. In this poem, it is the negative energy that breaks the poet's happiness that is metaphorically expressed in the last line in the above stanza.

COSMOS

The metaphor categorized as cosmos was found in Mohamad Safaat's Stars as follows:

Friend...

You like sun in my life

Which always lights every my step

So I do not feel alone

The predications of sun are:

1. The source of light

2. The source of warmth

3. The source of energy

Therefore, the sun of my life means it enlightens, warmth, and energizes the poet's life.

In the next poem by Mifta Sri Wahyuni, there are three metaphors categorized cosmos:

You are like the sun

That lighted my days

You are like the star

That lighted my dark sky

To understand the metaphor of sun, we refer to the predication of sun discussed previously. To understand the metaphor of star, we refer to the following predication:

1. The source of light in the night.

2. The sky object that navigates the sailors.

And the predications of the dark sky are:

1. Sky is the unlimited cosmos.

2. Dark, the situation in which nobody can see anything.

By combining the metaphors of the sun the star and dark sky, we can infer the intended meaning of this poem. It is about someone special to the poet, i.e. the one who makes her happy as the sun lighted the days and star that lighted the night.

BEING

The poem by Muthmainnah Nasaru entitled I'm Hurt that contains being is as follows:

Friend...

Because of you, I am hurt

This feel make me hurt

Hurt...like a knife hit my deep heart.

Deep heart might be categorized being since it is a psychological condition. It is a metaphor of the poet who is suffering or hurt psychologically due to the "you" act that hurt her. 


\section{THE FREQUENCY OF EACH CATEGORY}

The quantitative analysis on the semantic filed was conducted to find the frequency of the category. It is to find which category dominates the poems written by the students. It is presented in the following table.

TABLE 2 The frequency of each category

\begin{tabular}{cllll}
\hline \multirow{2}{*}{ NO } & & \multicolumn{2}{c}{ The Frequency } & \multirow{2}{*}{ The Place } \\
\cline { 3 - 5 } & & \multicolumn{2}{c}{ The Sum } & Percentage \\
\hline 1 & Human & 40 & $31.20 \%$ & 1 \\
\hline 2 & Animate & 2 & $1.60 \%$ & 7 \\
\hline 3 & Living & 6 & $4.70 \%$ & 6 \\
\hline 4 & Object & 10 & $7.80 \%$ & 5 \\
\hline 5 & Terrestrial & 2 & $1.60 \%$ & 7 \\
\hline 6 & Substance & 2 & $1.60 \%$ & 7 \\
\hline 7 & Energy & 19 & $14.80 \%$ & 3 \\
\hline 8 & Cosmos & 13 & $10.50 \%$ & 4 \\
\hline 9 & Being & 34 & $25.90 \%$ & 2 \\
\hline The Sum & 128 & $100 \%$ & \\
\hline
\end{tabular}

The table shows us the human category takes the first place. It means that this category dominates the categories. The second place was taken by being category. The lowest place was taken by animate, terrestrial, and substance.

\section{DISCUSSION}

In this session, the writer discusses the interpretation of the analysis. The discussion covered the semantic field category as reflected in poems and the interpretation of the quantitative data of the frequency of the category occurrence. In discussing the category, the writer presents the samples.

Lakoff and Johnson's hypothesis that metaphor has been the way of thinking is proven in the poems by the students of English Department of the State University of Gorontalo. Those poems show that the students perceive the reality in semantic field category discussed previously. Referring to the human perception categorized in semantic field proposed by Halley as cited in Wahab (1991), we can see that the students' perceptions was distributed in the semantic category. Take the sample poem by Ayu Amelia Lihawa. She perceives herself as the Spiderman or superman. In the lines, she seems to perceive herself in the imaginative superheroes and realizes that she is not as super as them. The phrase even though suggested that she has a strong aspect although she as not as strong as the superheroes.

The other poet, Rafika Paputungan, perceives her teacher in her parents' figure that is categorized human. Parents' predications are protection, love, caring, and guidance. This perception was written in her poem in order to respect or to idolize her teacher. In being category, Muthmainnah Nasaru in her poem I'm Hurt. In this poem she expressed her suffering due to her bad friend. She perceives the state suffering in being category, heart. Heart is feeling and feeling belongs to being.

In terms of frequency, it is dominated by human and being. The frequency of human 40 is 128 or $31.25 \%$. The frequency of being is 34 and thus $26.60 \%$. This can be explained by the 
thought that human perceives the reality he can sense. It means that the students' perception was mostly impacted by the two semantic fields. This phenomenon was discussed by Wahab (1990, 1991) that the metaphor was influenced by human's interaction with the environment. Wahab's thought was found in the poems written by the students. The category that dominates the students' perception is human. It means that the students who wrote the poems interacted more frequently with human more than the others.

The quantitative data suggests that the students' interaction with human is in the highest position. It means that the students, as suggested by the quantitative data, interact with the other more than with the others. In other words, their dimension as the social beings is stronger than the other ones.

\section{CONCLUSION}

Metaphor is not only ornament in poems. It is also the method of thinking. If we think that poem is the media of expressing of idea, then we believe that metaphor used in poems is also the method of thinking. The students as the poet think of the reality metaphorically. In terms of psycholinguistic, metaphor reflects the perception of human about the reality. Field semantic that is introduced by Halley, is reflected by the metaphor. The semantic field was dominated by the semantic fields categorized human in the first place and being in the second place. This suggested that the poets' interaction was mostly dominated by the interaction with human and being. The metaphor may be interpreted by finding the predication. Some metaphors have more than one predication that might be used for interpretation. Some have only one predication.

Based on the findings of this research, the writer has some suggestions to the readers. First, it is suggested that we do not treat metaphor as the ornament of language use; it is the tool of analyzing the way human perceive the reality. This study shows us that metaphor is not only the ornament of language. The study also shows that metaphor reflects the students' perception of the reality that is distributed in Halley's semantic field. Second, since metaphor has been used widely in communication, it would be possible if we study metaphor from sociolinguistic point of view and some other linguistics branches. Third, metaphor is not only the figurative language used in poems or any other literary works; it has been the way of perceiving the reality. Therefore, it is suggested that, in the context of university, the literary researcher to study the students' metaphor to map their perceptions of the reality. This map can be used to enrich the literary educational methodology.

\section{REFERENCES}

Chomsky, N. (1972). Language and mind. San Diego. Harcourt Brace Jovanovich.

Deichess D. (1964). A study of literature for readers and critics. New York: W.W. Norton \& Company Inc.

Kôvecses, Z. (2010). Metaphor. Oxford: Oxford University Press.

Kweldju, S. (2005). Metafora pungutan berpotens

mempengaruhi struktur konseptual bangsa Masyarakat Linguistik Indonesia Vol. 23. 193-2003. 
Lakoff, G \& Johnson, M. (1980). Metaphor we lived by. Chikago: University of Chikago Press.

Lihawa, K. (1999). Metafora dalam peristiwa perkawinan gorontalo (Unpublished Thesis) Malang: IKIP Negeri Malang.

Pateda, M. (1990). Aspek-aspek psikolinguistik. Ende: Nusa Indah.

Wahab, A. (1991). Isu linguistik dan pengajaran bahasa. Surabaya: Airlangga University Press.

Wahab, A. (1986). Javanese metaphor in discourse dnalysis (Dissertation) Urbana: Illinois University.

Wahab, A. (1990). Butir-butir linguistik. Surabaya: Airlangga University Press. 